Housing and Aboriginal People in Urban Centres: A Quantitative Evaluation

\author{
Dr. Yale D. Belanger
}

Associate Professor, Department of Native American Studies /

Adjunct Associate Professor, Faculty of Health Sciences, University of Lethbridge

Gabrielle Weasel Head

Independent Scholar, Calgary, $A B$

Dr. Olu Awosoga

Assistant Professor, Faculty of Health Sciences, University of Lethbridge

aboriginal policy studies Vol. 2, no. 1, 2012, pp.4-25

This article can be found at:

http://ejournals.library.ualberta.ca/index.php/aps/article/view/17705

ISSN: $1923-3299$

Article DOI: http://dx.doi.org/10.5663/aps.v2i1.17705

aboriginal policy studies is an online, peer-reviewed and multidisciplinary journal that publishes original, scholarly, and policy-relevant research on issues relevant to Métis, non-status Indians and urban Aboriginal people in Canada. For more information, please contact us at apsjournal@ualberta.ca or visit our website at www.ualberta.ca/nativestudies/aps/. 


\title{
Housing and Aboriginal People in Urban Centres: A Quantitative Evaluation
}

\author{
Dr. Yale D. Belanger ${ }^{1}$ \\ Associate Professor, Department of Native American Studies / \\ Adjunct Associate Professor, Faculty of Health Sciences, University of Lethbridge \\ Gabrielle Weasel Head \\ Independent Scholar, Calgary, $A B$ \\ Dr. Olu Awosoga \\ Assistant Professor, Faculty of Health Sciences, University of Lethbridge
}

\begin{abstract}
This paper explores the current state of urban Aboriginal housing in Canada, by providing an up-to-date mapping of national urban Aboriginal housing conditions. This paper demonstrates that home ownership helps to reduce the gap between mainstream and Aboriginal rates of core housing need, for Aboriginal renters are substantially worse off than their non-Aboriginal counterparts in terms of core housing need and overcrowding. Métis and Non-Status Indians are also more likely to become homeowners than Status Indians and Inuit. A cyclical process is identified that hinders urban Aboriginal homeownership, and home rental advancement is also discussed. Existing federal housing programs are inadequate to address the housing and homeless issues identified. We highlight the need to establish proactive policies, the goal being to facilitate individual transition into urban centres, thereby helping to ameliorate existing housing disparities.
\end{abstract}

\section{Introduction}

The National Aboriginal Housing Association (NAHA) estimated in 2006 that 73.4 percent of Aboriginal households live off the reserve, up from 70.6 percent in 2001 (NAHA $2009,6) .{ }^{2}$ That year the Canada Census concluded that 54 percent of the national Aboriginal population lived in cities (Environics Institute 2010,24); and that this population is younger and growing more rapidly than the non-Aboriginal population due, in part, to high birth and fertility rates and urban relocation from the surrounding First Nations and between rural and urban communities (see Environics Institute 2010). Also in 2006, the National Aboriginal Health Organization (NAHO) estimated that more than one-third of the national Aboriginal population lived in unsuitable, inadequate, or unaffordable housing as compared to 18 percent of the non-Native population (see Belanger 2007). Accepting the fact that adequate, affordable, and suitable housing contributes directly to improved health and well-being; that they are directly linked to an individual's ability to participate in the economy and general society; and that housing security is connected to improved educational attainment levels, this paper responds to the question, "What is happening right now?" in order to present a national level portrait of the current urban Aboriginal housing situation in Canada.

aboriginal policy studies, Vol. 2, no. 1, 2012

www.ualberta.ca/nativestudies/aps/

ISSN: 1923-3299 
In an effort to determine the state of urban Aboriginal housing and how it can be improved, we will produce an assessment of the people and place in the moment in order to provide:

1) An up-to-date mapping of Aboriginal people's housing conditions in urban areas. The term "housing conditions," as used here, is intended to signify a continuum of housing conditions, from owner-occupied, rented, and social housing to "couch surfing" (i.e., staying with friends and with relatives in multi-generational and multi-family homes), and living in shelters; and,

2) The data needed for scholars to pursue additional research aimed at developing rigorous and refined predictive models of inquiry.

This paper will proceed as follows. First, there will be a brief history of Canadian housing policy and an elaboration of where urban Aboriginal peoples fit into the overall bureaucratic/policy processes, followed by a discussion of urban Aboriginal housing trends. An analysis of Aboriginal Peoples Survey (APS 2006) data is provided to reveal the types of Aboriginal urban households (e.g., owner and private rented). ${ }^{3}$ These data inform our analysis of housing affordability, specifically the percentage of households presenting a shelter-to-income ratio (STIR) of 30 percent or higher. These categories were thoughtfully chosen due to their capacity to influence Aboriginal mobility, result in family instability, and lower youth educational outcomes and employment prospects.

\section{Urban Aboriginal People and Housing Policy Background}

Poor urban Aboriginal housing conditions should be somewhat surprising, given the federal government's obsession with Aboriginal housing conditions dating to Canadian Confederation in 1867. A scan of early Indian Agent reports produced during the 1870s highlights bureaucratic enthusiasm for Aboriginal people adopting western-style housing, thus ensuring sanitary conditions and ultimately civility. Perry (2003) has explored this link between colonial desires to improve Aboriginal housing and the corresponding societal diffusion of housing, gender, and family-related ideals, and has noted that limited federal resources were assigned to facilitate this transition. By the early twentieth century, bureaucratic attention had shifted away from housing to securing land surrenders and ensuring residential school attendance (e.g., Martin-McGuire 1998; Miller 2000; Milloy 2000). Reserve-housing policy fell by the wayside until the mid-1950s, but increased interest did not lead specifically to direct improvements. By 1966, federal negligence was exposed in media reports highlighting a full-blown national reserve-housing crisis and a desperate need for "12,000 new homes over a five-year period to meet a backlog of approximately 6,000 units and to take care of new family formation of about 1,250 a year" (Canada 1966, 59). Later that year, Arthur Laing, the Minister of Northern Affairs and National Resources, bowed to public pressure and announced a $\$ 84.5$ million federal expenditure to improve the existing poor state of reserve housing (Canada 1966). ${ }^{4}$

No mention was made of urban Aboriginal housing, which reveals Ottawa's emphasis on reserve community concerns, and its ignorance of what Aboriginal Senator Jim Gladstone (Blood) identified in 1967 as "a great number of Indians . . . moving to the cities and towns to get jobs," and who "need help in getting re-established" (Canada 1967, 1068). 
A corresponding investigation into Canada's lackluster public housing ventures culminated in 1969 when the minister responsible for housing, Paul Hellyer, released the Report of the Federal Task Force on Housing and Urban Development. Ottawa responded by establishing the Ministry of Housing and Urban Affairs in 1971, notwithstanding the Canadian Housing Mortgage Corporation's concerns about direct government involvement with housing policy and programs (Rose 1980). This new ministry also allocated $\$ 200$ million to a number of demonstration-housing projects ${ }^{5}$ leading to, among others, the Kinew Housing Corporation (Walker 2004; also 2008). The Kinew Housing Corporation was the nation's first Aboriginal directed non-profit urban housing corporation, and it emphasized the acquisition and rehabilitation of older homes that were rented to low-income families. Its success stimulated the creation of five more urban Aboriginal non-profit housing societies between 1972 and 1975, located across Canada that would become the prototype for more than one hundred such corporations currently operating nationally.

Coincident with these projects' emergence was escalating Aboriginal urbanization, which was typified by First Nations residents emigrating to the city for the promise of improved housing conditions, as well as for enhanced educational and employment opportunities. Ottawa's program response was erratic, but with federal encouragement, and an internal desire to assist rural and urban low-income Aboriginal people, the CMHC established the Rural and Native Housing Program in 1974, followed in 1978 by the Urban Native Housing Program and the On-Reserve Housing Program. The Congress of Aboriginal Peoples (CAP) representing Non-Status Indians, a growing majority of which was living in urban centres, allied with the CMHC to advance a plan that envisioned Ottawa supplying mortgage interest assistance through non-repayable subsidies over the mortgage's term. Several Friendship Centres and tribal councils subsequently sponsored a variety of housing initiatives, and today more than one hundred urban Aboriginal housing institutions, responsible for over ten thousand federal rental units, operate in all major Canadian urban centers (Manitoba Urban Native Housing Association 2012).

Among the more notable initiatives was the Urban Native Additional Assistance program, established in 1984. This program bridged the operating costs-operating income gap to "put urban Aboriginal housing institutions on a viable financial footing for the first time while also facilitating operating enhancement in the way of administration, counseling, and maintenance regimes that have contributed significantly to the success of the urban Aboriginal housing institutions" (Congress of Aboriginal Peoples 2004). The CMHC's willingness to recognize this initiative as separate from similar mainstream programs was innovative, and it further offered administrators the freedom to formulate and provide Aboriginal-specific services that embraced counseling, factored in the increased spending on administration, considered the role and importance of non-traditional households, and recognized its clients' endemic low-income status.

Unfortunately, a series of Progressive Conservative cutbacks in the late 1980s jeopardized these and other projects, including the Rural and Native Housing Program, which was terminated in 1991. Ottawa in the interim managed to cobble together assorted strategies to enhance urban Aboriginal housing, which included the Remote Housing Program and a host of complementary initiatives. The theme of devolution is evident, however. As the federal government extricated itself from providing urban Aboriginal 
housing programming, a coterie of private, public, and third sector parties filled the policy void with a complex array of still-operational programs that remain burdensome to navigate. Currently, for example, low-income Aboriginal people living off-reserve are eligible for general CMHC housing programs available to all Canadians. Then there's the \$1 billion Affordable Housing Initiative, which sought to boost the affordable housing supply through federal cost-sharing accords with provincial and territorial governments. Ottawa also spends $\$ 2$ billion annually on federal programs accessible to Aboriginal people, which include Public Housing, Non-Profit Housing, Rent Supplement, Rural and Native Housing, Urban Native Housing and Cooperative Housing. With the exception of the Urban Native Housing Program, which provides financial assistance to Aboriginal non-profit organizations, and Aboriginal co-op groups that own and operate urban rental housing projects, there are relatively few urban Aboriginal housing-specific programs.

What is striking is the level of attention paid to non-Aboriginal housing issues outside of the reserves, and the limited impact of Canadian policies, generally, on both reserve and urban Aboriginal housing (Miron 1988; Rose 1980). Consequently, Aboriginal housing priorities have been and remain a conspicuously low priority when compared to macro, post-1945 Canadian housing policies. Ottawa's retreat from Aboriginal housing programming has compelled many academics and advocates alike to remind federal officials of Canada's responsibility to adopt a leading role in programming and policy development by virtue of its historic relationship with Aboriginal peoples (Graham and Peters 2002; National Aboriginal Housing Association 2004; Walker 2006, 2003). As eloquently stated by the National Aboriginal Housing Association, "[T]he federal government's fiduciary responsibility to Aboriginal persons applies to all Aboriginal persons regardless of whether they live on or off reserve" $(2009, \mathrm{i})$. As discussed in the following sections, it is apparent that this responsibility remains largely disregarded, as are those Aboriginal peoples seeking urban home ownership opportunities.

\section{Housing \& Urban Aboriginal Peoples}

According to 2006 Canada Census data, just over half (54\%) of those individuals identifying themselves as members of at least one of Canada's Aboriginal groups (Indian, Métis, or Inuit) resided in urban areas (see Environics Institute 2010; Belanger 2010). Finding suitable housing remains a challenge for many urban Aboriginal individuals and families. Using CMHC data, in $2006 \mathrm{NAHO}$ estimated that more than one-third of Canada's Aboriginal population lived in inadequate, unsuitable, or unaffordable housing, compared to 18 percent of the non-Aboriginal population. Further elaboration on the urban Aboriginal experience is difficult to undertake, although recent years have witnessed improved attempts at capturing this experience (see Walker 2008). On the one hand, we know that cities can offer enhanced educational opportunities, recreational options, and access to employment. Yet, when compared to mainstream Canadians, urban Aboriginal peoples experience lower incomes, higher rates of unemployment and poverty, and higher incidences of single parenthood and domestic violence (Hanselmann 2001; Lezubski, Silver, and Black 2000; Mendelson 2004). 
During the last two decades, the CMHC has frequently reported on urban Aboriginal living conditions. In 1991, for example, it identified that more than half of all national urban Aboriginal households fell below one or more of the housing standards. It also highlighted the substance of increasingly poor reserve-housing conditions; specifically, that housing-related health issues, family tensions, and violence were the three primary drivers of Aboriginal urban migration during the 1990s (CMHC 1996a; see also Barsh 1997). Several years later the CMHC $(1995,2)$ once again identified urban Aboriginal individuals as more apt to "lack sufficient income to obtain adequate, suitable rental accommodations ... without having to pay $30 \%$ or more of their gross household income." By 2006, the CMHC (2011) concluded that 20.4 percent of Aboriginal peoples were living in core housing need-almost double that of the non-Aboriginal population (12.7\%).

In terms of home ownership, many studies also confirm that urban Aboriginal peoples experience comparatively depressed living conditions, which has a negative impact upon individual and collective socio-economic outcomes. As the CHMC has determined, however, improving socio-economic conditions begins with adequate and affordable housing, and this is accomplished by establishing housing circumstances that meet three conditions:

- Adequate housing: a dwelling must have full bathroom facilities and, according to its residents, require no major repairs;

- Suitable housing: a dwelling must have enough bedrooms for the size and makeup of the occupying household, as defined by the National Occupancy Standards;

- Affordable housing: total shelter and utility costs must consume less than 30 percent of household income (CMHC 1996b, 1).

An individual or household whose housing does not meet one of these needs, and whose income is insufficient to afford rental housing that does meet these standards, is considered to be in core housing need. Often these three categories overlap or are identified in tandem. Notably, once adequate, suitable, and affordable housing is accessible and a sense of stability and security is in place, finding one's place in the city poses fewer challenges.

There is room for optimism, however, for the available data, as discussed below, shows improvement in recent years.

\section{Urban Aboriginal Housing: A Quantitative Perspective}

The 2006 Canada Census identified 12.4 million households nationally, of which 506,235 were Aboriginal households $(n=4.08 \%)$. An Aboriginal household is defined by the CMHC as one of the following:

- a non-family household in which at least 50 percent of household members selfidentified as Aboriginal; or,

- a family household that meets at least one of two criteria:

- at least one spouse, common-law partner, or lone parent self-identified as an Aboriginal; or,

- at least 50 percent of household members self-identified as Aboriginal (CMHC 2012). 
Between 1996 and 2006, a period of national urban Aboriginal growth, the number of off-reserve Aboriginal households grew. During this time, the Aboriginal population grew by 45 percent, nearly six times faster than the non-Aboriginal population's 8 percent rate of increase. As Table 1 illustrates, the number of urban Aboriginal households, as compared to non-Aboriginal households, did not grow at a proportionate rate. Of note, this 45 percent population growth rate includes large numbers of individuals reporting Aboriginal identity who had not previously identified as Aboriginal. We do not know fully the impact of this trend, but estimate that it would have a significant effect on an issue such as housing, for the majority of these people would have had a house before and after declaring Aboriginal identity (see, generally, Guimond, Robitaille, and Senécal 2009).

TABLE 1: Households, Canada 2001-2006

\begin{tabular}{|l|c|c|c|}
\hline & 2001 & 2006 & \% Change 2001-2006 \\
\hline Canada (all) & $11,562,975$ & $12,437,500$ & 9.3 \\
\hline Aboriginal (off-reserve) & 398,400 & 506,235 & 7.9 \\
\hline
\end{tabular}

Source: Statistics Canada (2009), 2006 Census: Family Portrait: Continuity and Change in Canadian Families and Households in 2006: Highlights; and Statistics Canada (2007), Aboriginal Population Profile.

In terms of home ownership, Table 2 illustrates that Aboriginal people are less likely to become homeowners. Greater attention has been directed at the various barriers to Aboriginal homeownership during the last fifteen years, yet minimal corrective policy interventions have been devised. Few of the assorted housing assistance programs are Aboriginal-specific, and rarely is the urban Aboriginal population targeted for assistance. Aboriginal-specific programs and policies are therefore needed to alleviate the everwidening gap that exists between those who can and cannot afford homeownership ( $c f$ Moore and Skaburskis 2004). These programs would, in turn, respond to forces unique to the Aboriginal experience. For example, Not In My Backyard (NIMBY) syndrome amongst potential neighbours has been identified as an issue that hinders Aboriginal renters, although NIMBY-ism tends not to typically influence homebuyers as significantly (e.g., Fiske, Belanger, and Gregory 2010). ${ }^{6}$ Consequently, we would suggest that low employment participation rates and low-wage jobs are the main obstacles hindering Aboriginal people from becoming homeowners. Similar trends are evident in Alberta, Saskatchewan, and Manitoba, all of which demonstrate substantial Aboriginal socio-economic disparity and a significant percentage difference in Aboriginal homeownership rates. 
TABLE 2: Home Ownership Rates, 2006

\begin{tabular}{|l|c|c|c|}
\hline \multicolumn{1}{|c|}{ Region } & \% Canada & \% Aboriginal (CMAs) & \% Difference \\
\hline Canada & 68.4 & 47.8 & 18 \\
\hline NL & 78.7 & 67.6 & 6.1 \\
\hline PEI & 74.1 & n/a & 20.1 \\
\hline Nova Scotia & 72 & 51.0 & 15.4 \\
\hline New Brunswick & 75.5 & 50.7 & 19.3 \\
\hline Quebec & 60.1 & 50.3 & 9.9 \\
\hline Ontario & 71 & 51.7 & 15.9 \\
\hline Manitoba & 68.9 & 46.6 & 25 \\
\hline Saskatchewan & 71.8 & 40.9 & 31.8 \\
\hline Alberta & 73.1 & 47.6 & 22.6 \\
\hline BC & 69.7 & 47.8 & 17.3 \\
\hline Yukon & 63.8 & n/a & 20.8 \\
\hline NWT & 52.9 & n/a & 1.7 \\
\hline Nunavut & 22.7 & n/a & -1 \\
\hline
\end{tabular}

Source: CMHC (2009a), Aboriginal Households in Canada, by Aboriginal Identity, Location and Tenure, Canada, Provinces and Territories, 2006.

Similar inequalities are increasingly apparent amongst several of the Aboriginal population's sub-groups, which in part would help to substantiate Wotherspoon's (2003) assertion that many cities nationally have become the core of an emerging Aboriginal middle class. It is telling to measure by identity which Aboriginal peoples are more likely to become homeowners. For example, according to Table 3, one is more likely to become a homeowner if one is Métis. Non-Status Indians rank second, and are more likely than Status Indians and Inuit, respectively, to become homeowners. ${ }^{7}$ Reduced, and in many instances increasingly uninhabitable, reserve housing stock also negatively impacts reserve home ownership numbers. Many Status Indians are consequently forced to relocate to the city, where NIMBY makes renting more difficult. This has a subsequent impact on all urban Aboriginal people, who are forced to compete with reserve immigrants (among others) for existing home rental and ownership opportunities. Status Indians, for whom the majority of government programming is intended, appear to be at a disadvantage for urban homeownership. It is important also to note the small populations of different groups (particularly Inuit) in many regions when utilizing these figures.

Upon further review, Table 4 suggests that the above-mentioned differences stabilize when we specifically appraise urban identity and home ownership. For the most part, with the exception of Manitoba, Saskatchewan and Alberta, urban centres are essentially "statusblind" when it comes to Aboriginal home ownership, as both Status and Non-Status Indians present similar home ownership rates. In the Prairie provinces, however, Status Indians do appear to be at a clear disadvantage. Socio-economic disparity is influential, but the sizeable statistical differences suggest that other forces are at play (e.g., racism, discrimination). The data also reveal that, similar to national trends, Métis in most regions find it less difficult becoming homeowners. We anticipate that urban Aboriginal housing issues will become 
more pronounced in Eastern Canada in the near future, due to that region demonstrating the fastest growing Aboriginal population nationally. Between 2001-2006, Nova Scotia's Aboriginal population grew by 95 percent, New Brunswick's by 67 percent, Newfoundland and Labrador's by 65 percent, Quebec's by 53 percent and Ontario's by 68 percent. In the western provinces, the fastest growth was observed in Manitoba, at 36 percent (Canada 2006).

TABLE 3: Aboriginal Homeownership in Canada by Identity, 2006

\begin{tabular}{|l|c|c|c|c|}
\hline Region & Status Indian & Non-Status Indian & Métis & Inuit \\
\hline Canada & $40.8 \%$ & $53.5 \%$ & $61.6 \%$ & $34.4 \%$ \\
\hline NL & $67.8 \%$ & $77.9 \%$ & $75.7 \%$ & $66.1 \%$ \\
\hline PEl & $57.1 \%$ & $52.9 \%$ & $47.8 \%$ & $0 \%$ \\
\hline Nova Scotia & $43.4 \%$ & $60.3 \%$ & $73.0 \%$ & $52.3 \%$ \\
\hline New Brunswick & $48.1 \%$ & $64.1 \%$ & $71.1 \%$ & $70.4 \%$ \\
\hline Quebec & $49.3 \%$ & $56.0 \%$ & $58.3 \%$ & $16.4 \%$ \\
\hline Ontario & $49.1 \%$ & $54.1 \%$ & $64.8 \%$ & $40.9 \%$ \\
\hline Manitoba & $24.6 \%$ & $42.9 \%$ & $60.8 \%$ & $40.0 \%$ \\
\hline Saskatchewan & $21.8 \%$ & $40.7 \%$ & $60.2 \%$ & $82.1 \%$ \\
\hline Alberta & $37.3 \%$ & $51.0 \%$ & $60.1 \%$ & $49.2 \%$ \\
\hline BC & $47.5 \%$ & $50.1 \%$ & $59.9 \%$ & $43.0 \%$ \\
\hline Yukon & $39.3 \%$ & $56.0 \%$ & $67.3 \%$ & $29.2 \%$ \\
\hline NWT & $53.2 \%$ & $49.5 \%$ & $59.4 \%$ & $37.9 \%$ \\
\hline Nunavut & $21.1 \%$ & $0.0 \%$ & $16.7 \%$ & $23.9 \%$ \\
\hline
\end{tabular}

Source: CMHC (2009a), Aboriginal Households in Canada, by Aboriginal Identity, Location and Tenure, Canada, Provinces and Territories, 2006.

TABLE 4: Aboriginal Homeownership by Identity, Living in CMAs ${ }^{8} 2006$

\begin{tabular}{|c|c|c|c|c|}
\hline Region & Status Indian & Non-Status Indian & Métis & Inuit \\
\hline Canada & $38.9 \%$ & $48.2 \%$ & $54.3 \%$ & $38.9 \%$ \\
\hline NL & $67.3 \%$ & $65.1 \%$ & $69.4 \%$ & $55.0 \%$ \\
\hline PEI & $\mathrm{n} / \mathrm{a}$ & $\mathrm{n} / \mathrm{a}$ & $\mathrm{n} / \mathrm{a}$ & $\mathrm{n} / \mathrm{a}$ \\
\hline Nova Scotia & $53.1 \%$ & $52.0 \%$ & $51.2 \%$ & $30 \%$ \\
\hline New Brunswick & $54.8 \%$ & $52.1 \%$ & $45.9 \%$ & $\mathrm{n} / \mathrm{a}$ \\
\hline Quebec & $51.7 \%$ & $52.4 \%$ & $50.8 \%$ & $38.5 \%$ \\
\hline Ontario & $47.5 \%$ & $50.4 \%$ & $58.3 \%$ & $31.9 \%$ \\
\hline Manitoba & $27.3 \%$ & $42.4 \%$ & $55.6 \%$ & $35.3 \%$ \\
\hline Saskatchewan & $24.5 \%$ & $39.6 \%$ & $53.8 \%$ & $\mathrm{n} / \mathrm{a}$ \\
\hline Alberta & $35.6 \%$ & $48.3 \%$ & $53.2 \%$ & $42.6 \%$ \\
\hline BC & $35.1 \%$ & $42.2 \%$ & $50.5 \%$ & 35.4 \\
\hline Yukon & $\mathrm{n} / \mathrm{a}$ & $\mathrm{n} / \mathrm{a}$ & $\mathrm{n} / \mathrm{a}$ & $\mathrm{n} / \mathrm{a}$ \\
\hline NWT & $\mathrm{n} / \mathrm{a}$ & $\mathrm{n} / \mathrm{a}$ & $\mathrm{n} / \mathrm{a}$ & $\mathrm{n} / \mathrm{a}$ \\
\hline Nunavut & $\mathrm{n} / \mathrm{a}$ & $\mathrm{n} / \mathrm{a}$ & $\mathrm{n} / \mathrm{a}$ & $\mathrm{n} / \mathrm{a}$ \\
\hline
\end{tabular}

Source: CMHC (2009a), Aboriginal Households in Canada, by Aboriginal Identity, Location and Tenure, Canada, Provinces and Territories, 2006. 
For this discussion, it is important to consider whether homeownership results in an improved living standard. Between 1996 and 2006, it was reported that the share of Aboriginal people living in crowded homes declined: in 2006, 11 percent of Aboriginal people lived in homes with more than one person per room, down from 17 percent in 1996. These and similar trends demand attention, for the Aboriginal population, as previously mentioned, is growing more than six times faster than the non-Aboriginal population, and their homeownership rates are not growing proportionately. This could lead to difficulties. In 2006, for instance, nearly one in four urban Aboriginal people lived in homes requiring major repairs, which was unchanged from 1996. In comparison with non-Aboriginal people, Aboriginal people were also almost four times as likely to live in a crowded dwelling, and they were three times as likely to live in a home in need of major repairs (Canada 2006). This reflects one aspect of core housing need, which the CMHC (2008) defines as "households that are unable to afford shelter that meets adequacy, suitability, and affordability norms. The norms have been adjusted over time to reflect the housing expectations of Canadians. Affordability, one of the elements used to determine core housing need, is recognized as a maximum of 30 percent of the household income spent on shelter." Figure 1 measures the combined level of Aboriginal core housing need (renters and owners) against comparable non-Aboriginal rates for each province and territory in 2006.

FIGURE 1: Percentage/Incidence of Aboriginal Core Housing Need by Province, 2006

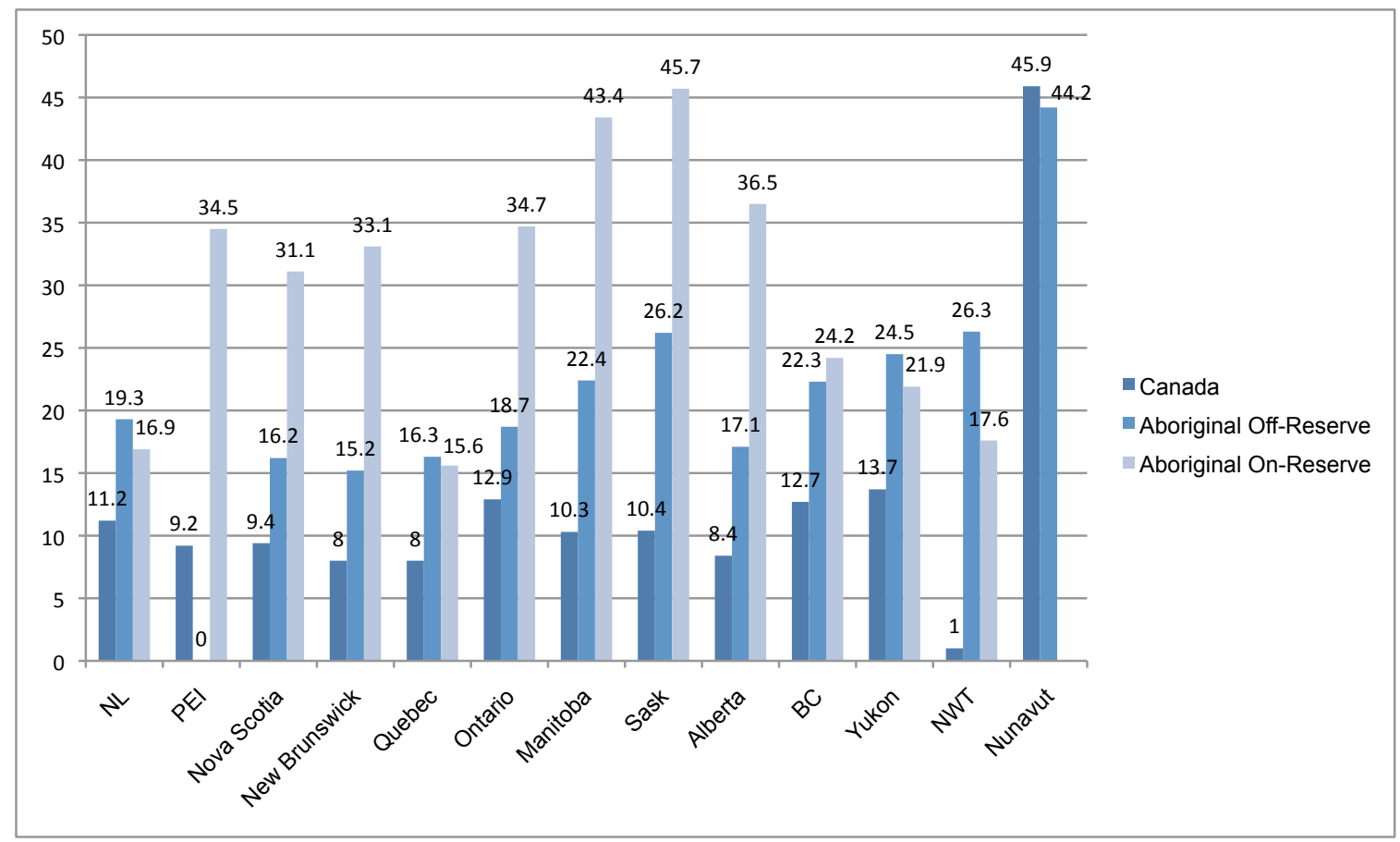

Sources: CMHC (2009c), Housing Conditions of Aboriginal Households Living Outside Reserves, Canada, Provinces, Territories and Metropolitan Areas, 2006; and, Housing Conditions of Aboriginal Households Living On-reserve, Canada, Provinces and Territories, 2006. For non-Aboriginal data, consult http://www.cmhc-schl.gc.ca/en/corp/about/cahoob/data/ data_025.cfm. 
Clearly the level of core housing need is greater among Aboriginal households than non-Aboriginal households nationally. More specifically, as Table 5 demonstrates, the urban Aboriginal population (20.4\%) presents a higher incidence of core housing need than the non-Aboriginal population (12.4\%). For the most part, urban Aboriginal households face reduced core-housing need when compared to on-reserve trends, although this trend is reversed in Newfoundland-Labrador, Quebec, Yukon, and the Northwest Territories, where reserve housing conditions slightly outpace urban Aboriginal housing conditions. The disparity grows as we move from Eastern to Western Canada, and it is evident that northern Aboriginal populations also confront significant core housing issues. The latter could be projected due in part to a harsher climate, leading to reduced ability to build efficient housing stock, which ultimately results in more overcrowding.

TABLE 5: Characteristics of Non-Reserve Households in Core Housing Need, Canada 2001, 2006

\begin{tabular}{|c|c|c|c|c|c|c|}
\hline & \multicolumn{2}{|c|}{ All Households } & \multicolumn{2}{|c|}{ Renters } & \multicolumn{2}{|c|}{ Owners } \\
\hline & $\begin{array}{c}\# \\
\text { Households } \\
\text { in Core } \\
\text { Housing } \\
\text { Need }\end{array}$ & $\begin{array}{l}\text { Incidence } \\
\text { of Core } \\
\text { Housing } \\
\text { Need }\end{array}$ & $\begin{array}{c}\# \\
\text { Households } \\
\text { in Core } \\
\text { Housing } \\
\text { Need }\end{array}$ & $\begin{array}{c}\text { Incidence } \\
\text { of Core } \\
\text { Housing } \\
\text { Need }\end{array}$ & $\begin{array}{c}\# \\
\text { Households } \\
\text { in Core } \\
\text { Housing } \\
\text { Need }\end{array}$ & $\begin{array}{c}\text { Incidence } \\
\text { of Core } \\
\text { Housing } \\
\text { Need }\end{array}$ \\
\hline \multicolumn{7}{|l|}{$\begin{array}{l}\text { Aboriginal Status } \\
(2006)\end{array}$} \\
\hline $\begin{array}{l}\text { Non-Aboriginal } \\
\text { Household }\end{array}$ & $1,412,580$ & 12.4 & 918,690 & 26.8 & 493,890 & 6.2 \\
\hline $\begin{array}{l}\text { Aboriginal } \\
\text { Household }\end{array}$ & 81,810 & 20.4 & 63,065 & 34.9 & 18,750 & 8.5 \\
\hline Status Indian & 38,740 & 24.8 & 31,440 & 37.9 & 7,305 & 10.0 \\
\hline Non-Status Indian & 15,860 & 20.3 & 12,440 & 35.1 & 3,415 & 8.0 \\
\hline Métis & 33,145 & 16.2 & 23,260 & 30.1 & 9,880 & 7.7 \\
\hline Inuit & 5,705 & 35.8 & 4,835 & 46.4 & 865 & 15.6 \\
\hline \multicolumn{7}{|l|}{$\begin{array}{l}\text { Aboriginal Status } \\
(2001)\end{array}$} \\
\hline $\begin{array}{l}\text { Non-Aboriginal } \\
\text { Household }\end{array}$ & $1,414,075$ & 13.5 & 955,315 & 27.9 & 458,760 & 6.5 \\
\hline $\begin{array}{l}\text { Aboriginal } \\
\text { Household }\end{array}$ & 71,265 & 24.0 & 56,170 & 37.7 & 15,090 & 10.2 \\
\hline Status Indian & 35,745 & 28.0 & 29,625 & 40.8 & 6,125 & 11.1 \\
\hline Non-Status Indian & 13,590 & 23.7 & 10,530 & 36.7 & 3,055 & 10.7 \\
\hline Métis & 24,665 & 19.2 & 18,055 & 33.3 & 6,615 & 8.9 \\
\hline Inuit & 4,680 & 35.8 & 3,805 & 43.3 & 870 & 20.3 \\
\hline
\end{tabular}

Source: NAHA (2009, A-9).

Poor Inuit housing conditions are significant issues that are too often overlooked despite demonstrated inferior housing conditions, and a small number of available studies provide us with some important insights. In Nunavut's capital Iqaluit (pop. 6,699), roughly 53 percent of Inuit live in overcrowded households, and 15 percent of the Territory's population is currently on wait lists for public housing. The Inuit Tapiriit Kanatami, the national voice for the 55,000 Inuit living in fifty-three communities across the Inuvialuit Settlement Region (Northwest Territories), Nunavut, Nunavik (Northern Quebec), and 
Nunatsiavut (Northern Labrador), has estimated that 3,300 houses are needed to address Nunavut's current housing shortage, followed by an annual allocation of 250 units to keep up with demand. A 2003 Housing Needs Survey in Newfoundland and Labrador highlighted 44 percent of Inuit households were in "core need" (NAHO 2008).

There is room for optimism, however-for, with the exception of the Inuit, all identity groups demonstrated generally similar declines in core housing need since 2001. Once again, Métis demonstrate higher urban living satisfaction by virtue of exhibiting lower core housing need, followed by Non-Status and Status Indians, respectively. The increased number of Aboriginal households in core housing need, on the other hand, offsets the declining percentage of core housing need. Here the number of homes increased from 71,000 to 81,800 , reflecting a 13.2 percent increase. Interestingly, Aboriginal renters $(34.9 \%)$ are more likely to be found in core housing need than non-Aboriginal renters $(26.8 \%)$, whereas the former account for 77 percent of Aboriginal household core housing need. As Figure 2 further suggests, to remain a renter in the city is to remain in constant danger of slipping into core housing need. It suggests further that attaining homeownership is a key driver leading to improved socio-economic conditions and, as such, greater socioeconomic equality. This is confirmed by measuring the incidence of Aboriginal to nonAboriginal core housing need for homeowners (8.5\% to 6.2\%) compared to renters $(34.9 \%$ to $26.8 \%$ ). Aboriginal individuals who become home owners are, therefore, statistically less likely to be in core housing need than renters, thus closing the gap between Aboriginal and non-Aboriginal socio-economic outcomes.

FIGURE 2: Core Housing Need Experienced by Urban Aboriginal Homeowners and Renters, 2006

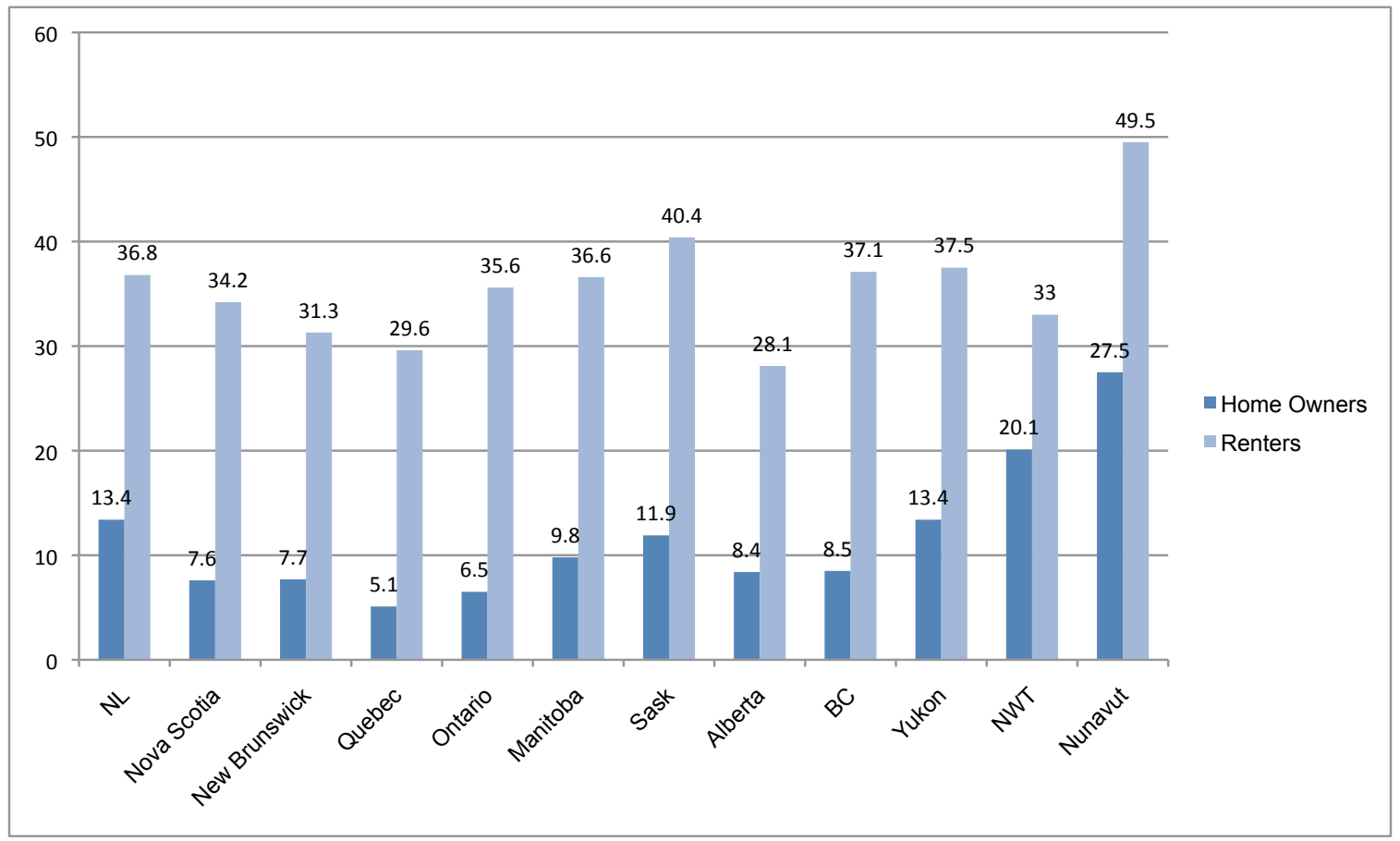

Sources: CMHC (2009c), Housing Conditions of Aboriginal Households Living Outside Reserves, Canada, Provinces, Territories and Metropolitan Areas, 2006; and, Housing Conditions of Aboriginal Households Living On-reserve, Canada, Provinces and Territories, 2006 (no data was available for PEI). 
As Figure 3 below illustrates, Aboriginal couples face the lowest incidence of need, as compared with lone parent households, which experience the highest incidence of need (43\%). This may be explained by the assumption that reasonably priced and appropriate sized housing for families is difficult to acquire. Housing need tends also to be skewed more toward young family households (which tend to be headed by single mothers) than in the non-Aboriginal population. Nearly 60 percent of core housing need households are under 45 years of age, while these age groups account for less than half of core need among non-Aboriginal households. Singles, and increasingly elders, require housing and support. Of particular concern are single mothers, which a recent Ontario study highlighted as follows (conclusions that arguably reflective of national trends): "Urban Aboriginal women are predominantly in the lower income brackets . . . with a large number of single-parent families and only moderate earnings, urban Aboriginal women face major challenges in finding childcare, obtaining employment and getting out of poverty" (Urban Aboriginal Task Force 2007, 159).

FIGURE 3: Distribution and Incidence of Non-Reserve Aboriginal Housing Need, 2006

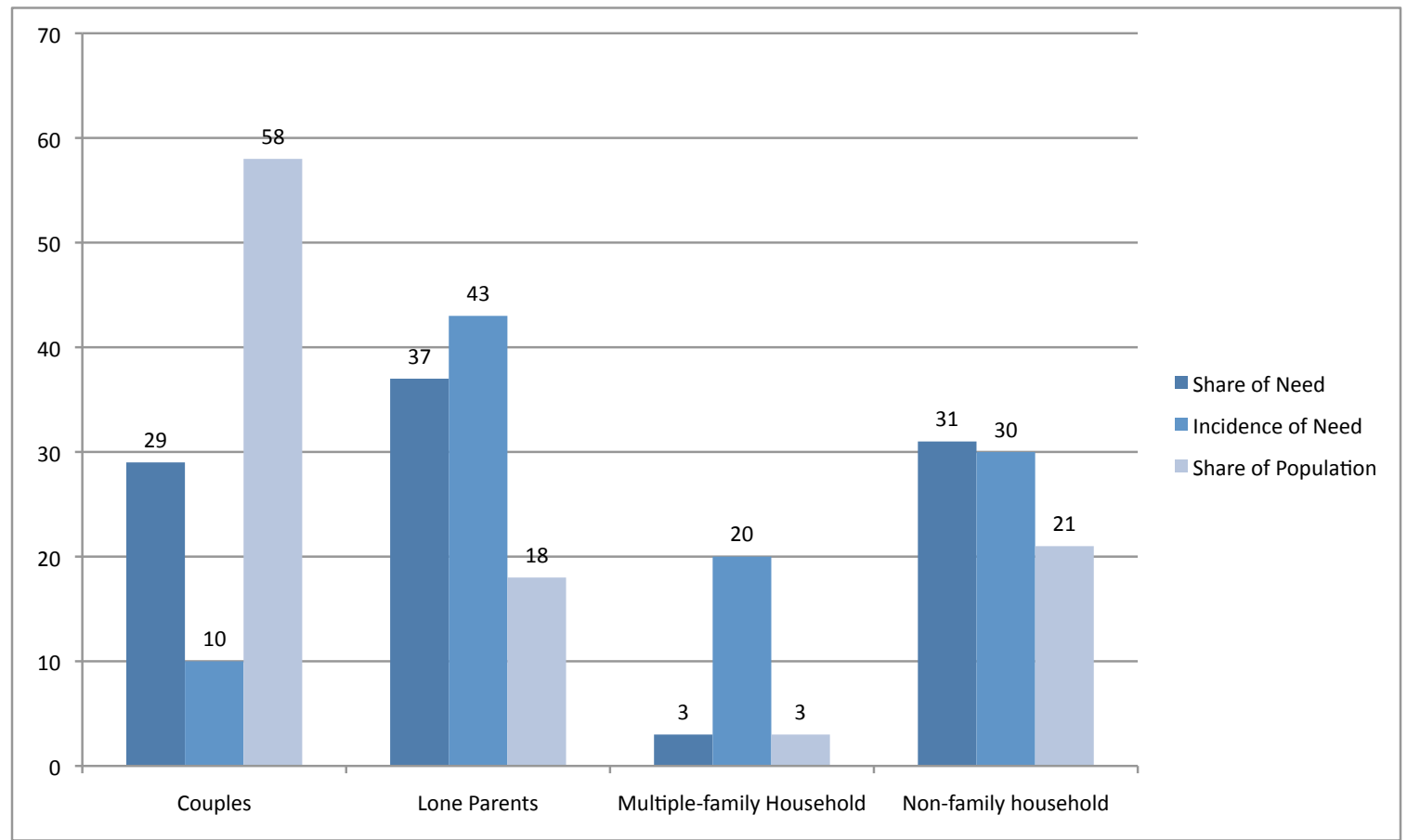

Source: NAHA 2009, A-10.

Although affordability is the primary concern, non-reserve Aboriginal households exhibited reduced levels of suitability and adequacy. As highlighted in Table 6, 28 percent of all Aboriginal households experience a crowding problem, or live in a dwelling identified as in poor shape $(23 \%)$. At levels more than twice that of non-Aboriginal households, affordability is a serious problem confronting Aboriginal renters and homeowners. This is compounded by the fact that non-reserve Aboriginal incomes are much lower, coming in, on average, at only 83 percent of that of non-Aboriginal households. 
TABLE 6: Type of Housing Problem Among Non-Reserve Aboriginal Households in Core Housing Need, 2006

\begin{tabular}{|c|c|c|c|c|c|c|}
\hline & \multicolumn{3}{|c|}{ Aboriginal Household } & \multicolumn{3}{|c|}{ Non-Aboriginal Household } \\
\hline & $\begin{array}{c}\text { Below } \\
\text { Adequacy } \\
\text { Standard }\end{array}$ & $\begin{array}{c}\text { Below } \\
\text { Affordability } \\
\text { Standard }\end{array}$ & $\begin{array}{c}\text { Below } \\
\text { Suitability } \\
\text { Standard }\end{array}$ & $\begin{array}{c}\text { Below } \\
\text { Adequacy } \\
\text { Standard }\end{array}$ & $\begin{array}{c}\text { Below } \\
\text { Affordability } \\
\text { Standard }\end{array}$ & $\begin{array}{c}\text { Below } \\
\text { Suitability } \\
\text { Standard }\end{array}$ \\
\hline & \multicolumn{6}{|c|}{ Percentage below each standard } \\
\hline Canada & $27.5 \%$ & $77.9 \%$ & $23.0 \%$ & $14.0 \%$ & $90.0 \%$ & $15.0 \%$ \\
\hline CMA (100k+) & $21.1 \%$ & $86.3 \%$ & $22.2 \%$ & $12.0 \%$ & $91.0 \%$ & $18.0 \%$ \\
\hline CAs (10k-100k) & $22.5 \%$ & $88.2 \%$ & $18.7 \%$ & $15.0 \%$ & $94.0 \%$ & $7.0 \%$ \\
\hline \multirow[t]{2}{*}{$\begin{array}{l}\text { Small Urban } \\
\text { Communities }\end{array}$} & $24.7 \%$ & $84.7 \%$ & $16.9 \%$ & $17.0 \%$ & $92.0 \%$ & $5.0 \%$ \\
\hline & \multicolumn{6}{|c|}{ Overall incidence for each standard } \\
\hline Canada & $5.6 \%$ & $15.9 \%$ & $4.7 \%$ & $1.8 \%$ & $11.2 \%$ & $1.8 \%$ \\
\hline CMA (100k+) & $4.5 \%$ & $18.3 \%$ & $4.7 \%$ & $1.6 \%$ & $12.3 \%$ & $2.4 \%$ \\
\hline CAs (10k-100k) & $4.0 \%$ & $15.7 \%$ & $3.3 \%$ & $1.5 \%$ & $9.5 \%$ & $0.7 \%$ \\
\hline $\begin{array}{l}\text { Small Urban } \\
\text { Communities }\end{array}$ & $3.6 \%$ & $12.3 \%$ & $2.4 \%$ & $1.5 \%$ & $7.8 \%$ & $0.5 \%$ \\
\hline
\end{tabular}

Source: NAHA (2009, A-9).

The CMHC in 1995 identified urban Aboriginal individuals as more likely to "lack sufficient income to obtain adequate, suitable rental accommodations . . . without having to pay $30 \%$ or more of their gross household income." This is described as the shelter to income ratio (STIR), which is the total annual household shelter costs derived from mortgage payments, property taxes, condominium fees, and utility payments; rental shelter costs consist of rent payments plus utilities. Households spending less than 30 percent of their incomes on shelter are classified as meeting the affordability standard. Households spending 30 percent or more of their incomes on shelter are classified as not meeting the affordability standard but are not necessarily experiencing housing affordability problems. As Table 7 illustrates, incomes and shelter costs in core need renter families is almost identical for Aboriginal and non-Aboriginal households. The APS data also demonstrates that the majority of the Aboriginal population maintains spouses or common-law partners in both big and mid-sized cities in provinces and territories, suggesting an emergent sense of family stability. Also, the largest proportion of primary household maintainers work full time, which confirms why their major source of income was wages and salaries in different provinces and territories. Once again, it would appear that forces such as discrimination, for instance, are driving higher rates of Aboriginal core housing need, in particular for renters.

Our APS data analysis does anticipate additional difficulties. Whereas, for example, Aboriginal houses in both big and mid-sized cities are suitable for permanent occupancy, the majority of these houses need major and minor repairs. Roughly 40 percent of Aboriginal people's dwellings in both big and mid-sized cities across all provinces and territories need either major or minor repairs. We observed that more Aboriginal people live in rental properties than own homes in Vancouver, Regina, Edmonton, Montreal, Winnipeg, Toronto, 
Yellowknife, and Whitehorse, regions that both demonstrate the highest national housing costs and largest urban Aboriginal populations. Reflecting on the rates of urban Aboriginal renters' core housing need, this foretells a serious problem. Also, the largest proportion of Aboriginal people's dwellings in big cities were constructed before 1980, trends that are evident in mid-sized cities where most homes were constructed before 1980. In Winnipeg and Toronto, for instance, the majority of houses that Aboriginal people currently occupy were built between 1946 and 1960. The age of these homes further implies that they are predisposed to problems, which means that while the majority of Aboriginal renters and homeowners may not currently be in core housing need, they may soon find themselves in difficulty. Absent immediate home repair expenditures, they can anticipate elevated core housing need status.

TABLE 7: Income and Shelter Costs Among Non-Reserve Households in Core Housing Need, 2006

\begin{tabular}{|c|c|c|c|c|}
\hline & \multicolumn{2}{|c|}{ Family } & \multicolumn{2}{|c|}{ Non Family } \\
\hline & \multicolumn{4}{|c|}{ Average Income } \\
\hline & Aboriginal & Non-Aboriginal & Aboriginal & Non-Aboriginal \\
\hline Canada & $\$ 23,203$ & $\$ 23,089$ & $\$ 13,818$ & $\$ 14,606$ \\
\hline CMAs $(100 \mathrm{k}+)$ & $\$ 21,340$ & $\$ 23,903$ & $\$ 13,978$ & $\$ 15,136$ \\
\hline CAs (10k-100k) & $\$ 19,555$ & $\$ 19,148$ & $\$ 12,919$ & $\$ 12,744$ \\
\hline \multirow[t]{2}{*}{$\begin{array}{l}\text { Small } \\
\text { Communities }\end{array}$} & $\$ 21,720$ & $\$ 18,042$ & $\$ 12,739$ & $\$ 12,879$ \\
\hline & \multicolumn{4}{|c|}{ Average STIR } \\
\hline Canada & 0.34 & 0.41 & 0.46 & 0.49 \\
\hline CMAs $(100 \mathrm{k}+)$ & 0.40 & 0.43 & 0.47 & 0.49 \\
\hline CAs (10k-100k) & 0.42 & 0.43 & 0.49 & 0.47 \\
\hline \multirow[t]{2}{*}{$\begin{array}{l}\text { Small } \\
\text { Communities }\end{array}$} & 0.36 & 0.40 & 0.48 & 0.49 \\
\hline & \multicolumn{4}{|c|}{ Average Shelter Costs } \\
\hline Canada & $\$ 659$ & $\$ 790$ & $\$ 528$ & $\$ 591$ \\
\hline CMAs $(100 \mathrm{k}+)$ & $\$ 714$ & $\$ 816$ & $\$ 548$ & $\$ 618$ \\
\hline CAs (10k-100k) & $\$ 683$ & $\$ 687$ & $\$ 523$ & $\$ 517$ \\
\hline $\begin{array}{l}\text { Small } \\
\text { Communities }\end{array}$ & $\$ 650$ & $\$ 654$ & $\$ 505$ & $\$ 507$ \\
\hline
\end{tabular}

Source: NAHA (2009, A-13).

\section{Conclusions}

At a national level, urban Aboriginal homeownership and rental rates are lower than those of mainstream Canada, and Aboriginal people tend to present higher core housing needs and lower income levels. We conclude that national policies are needed to aid urban Aboriginal renters and homeowners specifically, which would help ameliorate elevated urban Aboriginal homelessness. This is needed for as the above analysis shows, home ownership reduces the gap between mainstream and Aboriginal core housing need. It illustrates further that Aboriginal homeowners become close to the socio-economic equivalent of non-Aboriginal homeowners in terms of urban living satisfaction. The same 
cannot be said for Aboriginal renters, who are considerably worse off than their nonAboriginal counterparts, and present higher rates of core housing need and overcrowding, even though Aboriginal renters show similar to mainstream renter incomes and STIRs. Lower labour market and educational outcomes are powerful influences, but the data demonstrates the gap in each case to be closing. Hence we conclude that reasons beyond affordability are at play, which might include individual and community-driven resistance to Aboriginal housing initiatives and Aboriginal emigration to the city. Landlords may argue that this is more reflective of reserve émigrés lacking basic life skills or knowledge about how to manage their finances. For potential homeowners, fear of the home buying process is also likely an issue as is the permanency associated with locking into a twentyfive-year mortgage.

A cyclical process hindering urban Aboriginal renter and homeownership advancement is evident. To elaborate, NIMBY results in fewer urban Aboriginal rental opportunities, which in turn leads to amplified rates of multi-family and multi-generational households. In most cases this means that the majority of people in each home are homeless by definition, as they confront overcrowding and other similar issues. ${ }^{9}$ Inter- and intra-municipal and inter- and intra-community mobility surfaces as individuals and families seeking out a sense of permanency become ever more mobile. Aboriginal neighbourhoods emerge in this environment, and while a sense of community may develop, local living conditions are often below acceptable standards, which negatively impacts sense of identity, self, and community. As a result, many individuals often fail as renters, which in turn thwarts folks from obtaining the skills that are transferable to becoming homeowners. Once again, this negatively impacts urban Aboriginal homeownership rates. Older housing stock tends to be the most affordable, but its frequent state of disrepair results in increased maintenance costs, thereby leaving the homeowner in constant danger of slipping into core housing need. It is reasonable to suggest that substandard housing conditions have become normalized amongst both reserve and urban Aboriginal populations, and that those in search of improved housing employ an imperfect gauge to determine what is acceptable. This point has yet to be confirmed, and is an important study in need of pursuit, as is supplementary work seeking to determine the impacts of the above-mentioned cyclical process and community building efforts.

This type of research would also help us answer why Métis and Non-Status Indians are more likely to become homeowners than Status Indians and Inuit. We can hypothesize that higher Métis homeownership rates can be traced to a lack of Aboriginal rights, or that they in part resulted from an assimilation policy that demanded quicker Métis acclimation to urban living and mainstream norms. Similar to Métis, Non-Status Indians were legislatively abandoned by Ottawa, and were forced eventually to navigate urban housing and rental markets. It could also be that a stereotype abounds amongst landlords and bankers perceiving Status Indians as lacking the needed collateral to secure a mortgage, and thus representing a bad risk to lenders; or that they lack the skills needed to ensure proper home maintenance, therefore making Non-Status Indians more desirable clients. In such instances the transition into urban society is riddled with obstacles, and this could be impeding urban Aboriginal homeownership rates and rental opportunities, while exacerbating what are already high rates of urban Aboriginal homelessness. Importantly, 
large numbers of Métis and smaller numbers of First Nations adults who had previously not self-identified as Métis and Aboriginal began reporting their Aboriginal identity from 1996 and 2001. This group of what is sometimes called "ethnically mobile" individuals often reveals better socio-economic performance than other Aboriginal peoples, which in turn helps to better explain the identified homeownership and home rental trends.

We do know that existing programs are inadequate to address the Aboriginal housing issues identified here, and that successful models such as Housing First have been largely overlooked as a means of improving existing conditions. Our analysis of the dedicated programming indicates further that urban Aboriginal housing issues and homelessness are not considered complementary issues, which means that a common ministry, department, and/or commission has yet to materialize to deal collectively with these concerns. We would recommend establishing proactive policies with the goal of facilitating individual transition into urban centres, while also exploring why discrimination and racism remains prevalent for urban Aboriginal renters and homeowners. More importantly, how do these combined issues influence urban Aboriginal homeownership, rental rates, and homelessness? In the spirit of the Truth and Reconciliation Commission's recently published recommendations (TRC 2012), ensuring improved public education of Aboriginal housing issues discussed in this paper is essential. Often identifying the cost of one's behaviours can lead to positive change. For instance, a recent report concluded that Alberta's total yearly external expenditures to combat poverty ranged from $\$ 7.1$ to $\$ 9.5$ billion (Briggs and Lee 2012). And yet, studies repeatedly demonstrate that preventative strategies could be effective in alleviating this staggering drain on that provincial economy. Proactive programming of this variety, while requiring an up-front expenditure, could be effective in combating the various urban Aboriginal housing issues identified above.

As the Nobel-Prize winning economist Amartya Sen (1999) has shown, poverty and social exclusion create barriers to community life participation, which are often seen in our children's inability to develop to their full potential. Ensuring adequate urban Aboriginal housing opportunities - either by enhancing home buying or rental opportunities - is an important first step in ending these inequalities. Toward this end, we endorse a number of recommendations we feel will assist in this matter:

1. Formally endorse the National Aboriginal Housing Association's call for a national nonreserve housing strategy. Specifically, the Government of Canada and the provincial and territorial governments need to meet fully, in co-operation with Aboriginal people and within ten years, the need for adequate housing of Aboriginal people not living on reserves.

2. Establish a Housing and Homelessness Secretariat devoted to reserve and urban Aboriginal housing and homelessness issues.

3. Additional research is required to determine why, for example, Métis and Non-Status Indians are more likely to become homeowners than Status Indians and Inuit.

4. Reinstate and increase funding for new social housing and mortgage subsidies under the CMHC's Aboriginal off-reserve programs.

5. Provide greater autonomy and flexibility to Aboriginal organizations delivering 
programs in rural areas and to urban social housing corporations.

6. For both urban Aboriginal renters and homeowners, explore the socio-economic reasons leading to core housing need.

7. Determine whether low labour market and educational outcomes are impeding urban Aboriginal homeownership.

8. A national study is required to explore the impacts of NIMBY on rental opportunities, and the related influence over urban Aboriginal homeless rates.

9. More attention needs to be devoted to creating proactive policies to assist with urban Aboriginal homeownership and improving rental opportunities. This is by no means a call for augmented assimilation policies, but rather a call for appropriate ameliorative strategies to assist with urban acclimation and attaining homeownership.

10. Provide rental subsidies as a cost-effective option where rental markets exist.

11. Public education strategies need to be developed to show NIMBY's negative impact of on rental opportunities, and how improved homeownership rates translate into lower public response costs for poverty programming.

\section{Notes}

1. The author would like to thank the following: Nathan Roth and Charley Waters for their outstanding research assistance; the four anonymous reviewers' helpful comments; and my Alberta Homelessness Research Consortium (AHRC) colleagues, Dr. John Graham (Calgary) and Giri Puligandla (Homeward Trust Edmonton), for their perceptive comments on an earlier draft, all of which improved this report substantially. The National Association of Friendship Centres (NAFC) and the Office of the Federal Interlocutor for Métis and Non-Status Indians (OFI), Ottawa, funded the research from which this article is derived (See Belanger, Weasel Head, and Awosoga 2012).

2. The term "Aboriginal peoples" indicates any one of the three legally defined culture groups that form what are known as Aboriginal peoples in Canada (Métis, Inuit, and Indian) and who self-identify as such. The term First Nation is used here to denote a reserve community, or band. The term Indian, as used in legislation or policy, will also appear in discussions concerning such legislation or policy. The term Indigenous, as used here, does not represent a legal category. Rather, it is used to describe the descendants of groups in a territory at the time when other groups of different cultures or ethnic origin arrived there, groups that have almost preserved intact the customs and traditions of their ancestors similar to those characterized as Indigenous, and those that have been placed under a state structure which incorporates national, social, and cultural characteristics distinct from their own.

3. The Aboriginal Peoples Survey was a national survey of Aboriginal peoples (First Nations peoples living off-reserve, Métis and Inuit) in Canada. The survey provides 
valuable data on the social and economic conditions of Aboriginal people six years of age and over. The APS complements other sources of information and surveys, including the Census of Population and the National Household Survey. The APS informs policy and programming activities that are aimed at improving the well-being of Aboriginal peoples and is an important source of information for a variety of stakeholders, including Aboriginal organizations, communities, service providers, researchers, governments, and the general public. The survey was carried out by Statistics Canada, with funding provided by three federal departments: Aboriginal Affairs and Northern Development Canada, Health Canada, and Human Resources and Skills Development Canada.

4. This would be $\$ 582,413,053$ in current dollars (February 2012), adjusted for inflation.

5. A demonstration project is conducted under government supervision, to better understand the issues and solutions associated with (in this case) rental housing. The goal is to review the project's operations for the purposes of devising best practices; and to then develop processes that result in improved levels of housing capacity and access to adequate and affordable housing.

6. NIMBY ("Not In My Backyard") is perceived as a problem to be resolved, and constituted as a "syndrome." NIMBY is positioned as a response to alleged social and economic threats associated with the siting of undesired facilities within a neighborhood or community. NIMBY resistance emerges in response to the perceived negative social character of non-market housing residents and fears that their presence will lead to devaluation of private property and disruption of community harmony and safety. Strategies to overcome NIMBY-ism range from consultation processes to creating equity insurance in order to protect homeowners from declining house values

7. It must be noted that these aggregate data include reserve data, and that Non-Status Indians are often denied the ability to live on reserve, which in turn precludes them from reserve home ownership.

8. A census metropolitan area (CMA) is formed by one or more adjacent municipalities centred on a large urban area (known as the urban core). A CMA must have a total population of at least 100,000, of which 50,000 or more must live in the urban core. A CMA is delineated using adjacent municipalities (census subdivisions) as building blocks. These census subdivisions (CSDs) are included in the CMA if they meet at least one of the following rules, which are ranked in order of priority. A CSD obeying the rules for two or more CMAs is included in the one for which it has the highest ranked rule. If the CSD meets rules that have the same rank, the decision is based on the population or the number of commuters involved. A CMA is delineated to ensure spatial contiguity.

9. In its recent attempts to develop a pan-Canadian definition of homelessness, the Canadian Homelessness Research Network (CHRN) has developed the following working classification: 
Homelessness describes a range of housing and shelter circumstances, with people being absolutely homeless at one end, and experiencing housing exclusion (being precariously or inadequately housed) at the other. That is, homelessness encompasses a range of physical living situations, organized here in a typology that includes:

1. Unsheltered, or absolutely homeless and living on the streets or in places not intended for human habitation;

2. Emergency Sheltered, including those staying in overnight shelters for people who are homeless, as well as Violence Against Women shelters;

3. Provisionally Accommodated, referring to those whose accommodation is temporary, and who do not have their own home or security of tenure; and finally,

4. Insecurely Housed, which describes people who are 'at risk' of homelessness, and whose current economic and/or housing situation is precarious or does not meet public health and safety standards. It should be noted that for many people homelessness is not a static state but rather a fluid experience, where people's shelter circumstances and options may shift and change quite dramatically and with frequency.

Homelessness can also be categorized by duration of homelessness that includes:

1. Brief homelessness (less than 30 days);

2. Short-term homelessness (less than a year); and,

3. Chronic homelessness (more than a year), which is more entrenched and long term.

4. Such periods of homelessness can be continuous in duration or episodic in which people rotate in and out of homelessness. 


\section{Bibliography}

Barsh, R. L. 1997. "Aboriginal People in an Urban Housing Market: Lethbridge, Alberta." Canadian Journal of Native Studies 27 (2): 203-14.

Belanger, Y. D. 2007. "Assessing Urban Aboriginal Housing Needs in Southern Alberta." Saskatchewan Institute on Public Policy, Public Policy Paper \#51.

-_- 2010. Ways of Knowing: An Introduction to Native Studies in Canada. Toronto: Nelson.

Belanger, Y. D., G. Weasel Head, and O. Awosoga. 2012. Housing and Homelessness of Urban Aboriginal People in Urban Centres. Ottawa: National Association of Friendship Centres/Office of the Federal Interlocutor for Métis and Non-Status Indians.

Briggs, A. and C. R. Lee. 2012. Poverty Costs: An Economic Case for a Preventative Poverty Reduction Strategy in Alberta. Calgary: Vibrant Communities Calgary.

Canada. 1966. Opening Statement by the Honourable Arthur Laing to the House of Commons Committee on Indian Affairs, Human Rights and Citizenship and Immigration (19 May): 4-5. Census. Statistics Canada Catalogue No. 91-558-XIE. Ottawa: Statistics Canada.

_-_. 1967. Senate Proceedings and Debates (10 March): 1068.

-_-. 2006. Aboriginal Peoples in Canada in 2006: Inuit, Métis and First Nations, 2006

CMHC. 1995. Housing Need in Metropolitan Areas, 1991: Canada's Aboriginal Peoples. Ottawa: CMHC.

- - . 1996a. Migration and Mobility of Canada's Aboriginal Population. Ottawa: CMHC.

- - . 1996b. The Housing Conditions of Aboriginal People in Canada. Ottawa: CMHC.

- _ . 2008. "CHMC Releases Comprehensive Report on Housing in Canada." Accessed 10 March 2012. http://www.cmhc-schl.gc.ca/en/corp/nero/nere/2008/2008-1113-0815.cfm.

-_- 2009a. Aboriginal Households in Canada, by Aboriginal Identity, Location and Tenure, Canada, Provinces and Territories, 2006. Ottawa: CMHC.

-_- 2009b. Housing Conditions of Aboriginal Households Living On-reserve, Canada, Provinces and Territories, 2006. Ottawa: CMHC.

- - - 2009c. Housing Conditions of Aboriginal Households Living Outside Reserves, Canada, Provinces, Territories and Metropolitan Areas, 2006. Ottawa: CMHC.

-_- 2011. 2006 Census Housing Series: Issue II-Off-reserve Non-Status Indian Households: Housing Conditions and Core Housing Need. Ottawa: CMHC.

-_- 2012. Housing in Canada Online: Definitions of Variables. Accessed 6 May 2012. http://cmhc.beyond2020.com/HiCODefinitions_EN.html

Congress of Aboriginal Peoples. 2004. Urban Native Housing Program. Ottawa: Congress of Aboriginal Peoples. 
Environics Institute. 2010. Urban Aboriginal Peoples Study. Accessed 22 May 2012. http:// uaps.ca/wp-content/uploads/2010/03/UAPS-Main-Report_Dec.pdf.

Fiske, J.A., Y. D. Belanger, and D. S. Gregory. 2010. “Outsiders in Their Homeland: Discursive Construction of Aboriginal Women and Citizenship." American Indian Culture and Research Journal 34 (3): 71-92.

Graham, K. A. H., and E. J. Peters. 2002. Aboriginal Communities and Urban Sustainability. Ottawa: Canadian Policy Research Networks.

Guimond, E., N. Robitaille, and S. Senécal. 2009. "Aboriginal Populations in Canadian Cities: Why are They Growing So Fast?” Canadian Issues (Winter): 11-18.

Hanselman, C. 2001. Urban Aboriginal People in Western Canada: Realities and Policies. Calgary: Canada West Foundation.

Lezubski, D., E. Black, and J. Silver. 2000. "High and Rising: The Growth of Poverty in Winnipeg." In Solutions that Work: Fighting Poverty in Winnipeg, ed. Jim Silver, 2651. Winnipeg and Halifax: Fernwood.

Martin-McGuire, P. 1998. First Nations Land Surrenders on the Prairies, 1896-1911. Ottawa: Indian Claims Commission.

Manitoba Urban Native Housing Association. 2012. History: The Historical Perspective. Accessed 5 May 2012. http://www.munha.ca/index.php?pid=3.

Mendelson, M. 2004. Aboriginal People in Canada's Labour Market: Work and Unemployment, Today and Tomorrow. Ottawa: The Caledon Institute of Social Policy.

Miller, J.R. 1996. Shingwauk's Vision: A History of Native Residential Schools. Toronto: University of Toronto Press.

Milloy, J. S. 1999. "A National Crime”: The Canadian Government and the Residential School System, 1879 to 1986. Winnipeg: University of Manitoba Press.

Miron, J. R. 1988. Housing in Postwar Canada: Demographic Change, Household Formation, and Housing Demand. Kingston and Montreal: McGill-Queens University Press.

Moore, E. and A. Skaburskis. 2004. "Canada's Increasing Housing Affordability Burdens." Housing Studies 19 (3): 395-413. http://dx.doi.org/10.1080/0267303042000204296.

National Aboriginal Housing Association (NAHA). 2004. A New Beginning: The National Non-Reserve Aboriginal Housing Strategy. Ottawa: National Aboriginal Housing Association.

-_- 2008. Homelessness and Housing Realities for Inuit: Background and Glossary. Ottawa: National Aboriginal Health Organization. Accessed 6 May 2012. http:// www.naho.ca/documents/it/2011_Homelessness-Housing-Realities-InuitWorkshop.pdf.

- - - 2009. A Time for Action: A National Plan to Address Aboriginal Housing. Ottawa: National Aboriginal Housing Association. 
Perry, A. 2003. "From 'the hot-bed of vice' to the 'good and well-ordered Christian home': First Nations Housing and Reform in Nineteenth-Century British Columbia." Ethnohistory 50 (4): 587-610. http://dx.doi.org/10.1215/00141801-50-4-587.

Rose, A. 1980. Canadian Housing Policies, 1935-1980. Scarborough, ON: Butterworth.

Sen, A. 1999. Development as Freedom. New York: Anchor Books.

Statistics Canada. 2009. 2006 Census: Family portrait: Continuity and Change in Canadian families and households in 2006: Highlights. Accessed 7 June 2012. http://www12. statcan.ca/census-recensement/2006/as-sa/97-553/p1-eng.cfm.

-_- 2007. Aboriginal Population Profile. 2006 Census. Statistics Canada Catalogue no. 92-594-XWE. Ottawa. Released January 15, 2008. Accessed 7 June 2012. http://www12.statcan.ca/census-recensement/2006/dp-pd/prof/92-594/ index.cfm? Lang=E.

Truth and Reconciliation Commission of Canada. 2012. Backgrounder on the Findings and Recommendations of Truth and Reconciliation Commission of Canada Interim Report. Accessed 11 March 2012. http://www.myrobust.com/websites/ trcinstitution/File/pdfs/Backgrounder-Interim\%20Report\%20ENG_Final.pdf.

Urban Aboriginal Task Force. 2007. Final Report. Toronto: Urban Aboriginal Task Force.

Walker, R. C. 2003. "Engaging the Urban Aboriginal Population in Low-Cost Housing Initiatives: Lessons from Winnipeg." Canadian Journal of Urban Research 12 (1): 99-118.

- - - 2004. The Early Years of Kinew Housing and the Urban Native Housing Program. Saskatoon: Federation of Saskatchewan Indian Nations.

—_- 2006. "Interweaving Aboriginal/Indigenous Rights with Urban Citizenship: A View from the Winnipeg Low-Cost Housing Sector, Canada." Citizenship Studies 10 (4): 391-411.

- - - 2008. "Social Housing and the Role of Aboriginal Organizations in Canadian Cities." IRPP Choices 14 (4): 1-18.

Wotherspoon, T. 2003. "Prospects for a New Middle Class among Urban Aboriginal People." In Not Strangers in These Parts: Urban Aboriginal Peoples, D. Newhouse and E. J. Peters, 147-66. Ottawa: Policy Research Initiative. 